\title{
ANALISIS FUNDAMENTAL, TEKNIKAL DAN MAKROEKONOMI HARGA SAHAM SEKTOR PERTANIAN
}

\author{
Danika Reka Artha \\ Noer Azam Achsani \\ Hendro Sasongko \\ Program Pascasarjana Manajemen Bisnis Institut Pertanian Bogor \\ Jl. Raya Pajajaran, Bogor 16143 \\ Email: danika_artha@yahoo.com
}

\begin{abstract}
Abstrak
Penelitian ini bertujuan untuk mengetahui pengaruh dari analisis fundamental, teknikal, dan faktor makroekonomi terhadap harga saham sektor pertanian. Metode yang digunakan adalah metode regresi panel dengan lama penelitian antara bulan Februari 2013 sampai dengan April 2013. Hasil penelitian menunjukan bahwa faktor Book Value per Share (BVS), Price to Book Value (PBV), Debt to Equity Ratio (DER), tren harga saham, BI rate, harga minyak dunia, dan kurs rupiah memberikan pengaruh signifikan terhadap harga saham sektor pertanian pada level $1 \%$.
\end{abstract}

Kata Kunci: Harga Saham Sektor Pertanian, Faktor Fundamental, Faktor Teknikal, Faktor Makroekonomi

\begin{abstract}
This study aimed to determine the effect of fundamental analysis, technical and macroeconomic factors on agricultural sector stock prices. The method used was panel data regression with time period between $\mathrm{Fe}$ bruary 2013 to April 2013. The results of this study indicated that factors Book Value per Share (BVS), Price to Book Value (PBV), Debt to Equity Ratio (DER), stock price tren, BI rate, world oil prices, and exchange rate has significant impact on the agricultural sector stock price at the level of $1 \%$.
\end{abstract}

Keywords: Agricultural Sector Stock Price, Fundamental Factor, Technical Factor, Macroeconomic Factor

\section{PENDAHULUAN}

Krisis ekonomi global yang terjadi pada triwulan IV tahun 2008 ditandai dengan melambatnya pertumbuhan ekonomi global sebagai dampak dari peningkatan harga komoditas dunia, terutama harga minyak dan pangan. Hal ini bertambah parah dengan krisis keuangan yang terjadi pada Amerika Serikat dan mengakibatkan penurunan industri keuangan global. Khusus untuk harga minyak sempat mencapai $\$ 133.930$ per barel yang merupakan rekor tertinggi sepanjang masa. Selain itu, krisis menyebabkan terjadinya kenaikan suku bunga dan nilai tukar US dolar (Bank Indonesia, 2011a). Nilai rata-rata kurs US dolar per bulannya meningkat sebanyak $6,94 \%$. Peningkatan kurs US dolar diikuti pula oleh peningkatan BI rate sebanyak $0,07 \%$ menjadi $8,67 \%$ pada tahun 2008. Begitu pula dengan pergerakan IHSG dan sektor-sektor di dalamnya mengalami pergerakan yang sangat fluktuatif (Bank Indonesia, 2011c).
Sektor pertanian memiliki kecenderungan penurunan yang signifikan. Pada penutupan indeks sektor pertanian akhir tahun 2007 berada pada harga Rp. 238.053 dan pada penutupan tahun 2008 mengalami koreksi pada harga Rp134.987 kemudian meningkat pada kisaran harga Rp273.932 pada 2009. Hal tersebut sejalan dengan pergerakan Indeks Harga Saham Gabungan (IHSG) secara menyeluruh, sehingga saham pada sektor pertanian memberikan cerminan perubahan harga saham pada IHSG (Bursa Efek Indonesia, 2011a \& 2011b).

Tabel 1 menunjukkan perubahan harga saham pada IHSG dengan sektor-sektor di dalamnya sebagai ukuran menarik tidaknya suatu investasi saham yang mengalami koreksi cukup tajam sebanyak $-77 \%$ pada tahun 2008 dibandingkan tahun 2007 dan keseluruhan sektor saham waktu itu juga mengalami koreksi pada harga sahamnya. Salah satu sektor saham yang paling terkena dampak dari perubahan krisis ekonomi global adalah sektor pertanian yang mengalami penurunan sebanyak $-150,68 \%$ pada tahun 2008 dibandingkan tahun 2007. 
Tabel 1. Perubahan Harga Saham Setiap Sektor dan IHSG Periode 2005-2011

\begin{tabular}{lccccccc}
\hline \multirow{2}{*}{ Sektor Usaha } & \multicolumn{7}{c}{ Tahun } \\
\cline { 2 - 8 } & $\mathbf{2 0 0 5}$ & $\mathbf{2 0 0 6}$ & $\mathbf{2 0 0 7}$ & $\mathbf{2 0 0 8}$ & $\mathbf{2 0 0 9}$ & $\mathbf{2 0 1 0}$ & $\mathbf{2 0 1 1}$ \\
\hline Pertanian, Peternakan Kehu- & - & $146,9 \%$ & $126,09 \%$ & $-150,68 \%$ & $90,81 \%$ & $30,30 \%$ & $22 \%$ \\
tanan dan Perikanan & & & & & & & \\
Pertambangan dan Penggalian & - & $54,4 \%$ & $250,41 \%$ & $-256,36 \%$ & $151,06 \%$ & $48,59 \%$ & $14,93 \%$ \\
Industri Dasar dan Kimia & - & $41,1 \%$ & $61,83 \%$ & $-70,06 \%$ & $102,93 \%$ & $41,37 \%$ & $49,04 \%$ \\
Aneka Industri & - & $38,8 \%$ & $68,01 \%$ & $-92,36 \%$ & $179,84 \%$ & $60,78 \%$ & $117,99 \%$ \\
Barang Konsumsi & - & $39,8 \%$ & $11,10 \%$ & $-27,82 \%$ & $105,39 \%$ & $63,06 \%$ & $96,03 \%$ \\
Properti dan Real Estate & - & $91,7 \%$ & $104,87 \%$ & $-120,67 \%$ & $41,85 \%$ & $38,35 \%$ & $56,17 \%$ \\
Transportasi dan Infrastruktur & - & $63,2 \%$ & $13,28 \%$ & $-49,73 \%$ & $48,57 \%$ & $12,45 \%$ & $-3,99$ \\
Keuangan & - & $57,1 \%$ & $26,14 \%$ & $-40,78 \%$ & $70,94 \%$ & $54,82 \%$ & $63,15 \%$ \\
Perdagangan Jasa \& Investasi & - & $40,2 \%$ & $42,59 \%$ & $-88,67 \%$ & $85,91 \%$ & $71,92 \%$ & $111,12 \%$ \\
Manufaktur & - & $39,9 \%$ & $41,49 \%$ & $-58,44 \%$ & $123,65 \%$ & $55,60 \%$ & $87,60 \%$ \\
IHSG & - & $55,3 \%$ & $52,08 \%$ & $-77,01$ & $86,98 \%$ & $46,13 \%$ & $3,20 \%$ \\
\hline
\end{tabular}

Sumber: Bursa Efek Indonesia, 2011b

Sektor pertanian merupakan sektor yang berperan penting dalam perekonomian nasional, karena lebih dari 40\% masyarakat Indonesia menggantungkan hidupnya pada sektor ini, baik secara langsung maupun tidak langsung. Sektor ini juga menjadi sektor primer bagi banyak sektor, karena tidak sedikit hasil yang diproduksi oleh sektor pertanian juga diperlukan oleh sektor lain. Laju pertumbuhan Produk Domestik Bruto (PDB) sektor pertanian mampu mengungguli sektor lainnya yaitu sebesar 26,32\% (Badan Pusat Statistik, 2010). Namun akibat kondisi krisis, kontribusi sektor pertanian terhadap PDB menurun hingga menjadi 13,61\% pada tahun 2009 (Badan Pusat Statistik, 2010).

Dalam penelitian ini, akan dilihat bagaimana pengaruh analisis fundamental, analisis teknikal, dan analisis faktor-faktor makroekonomi terhadap harga saham, khususnya pada perusahaan sektor-sektor pertanian di Bursa Efek Indonesia (BEI) untuk menentukan keputusan investasi bagi investor yang ingin menginvestasikan dananya pada sektor pertanian tersebut. Periode penelitian diambil dari tahun 2005 sampai dengan tahun 2011 dengan jumlah perusahaan di sektor pertanian yang sudah listing sebanyak delapan perusahaan.

\section{Rumusan Masalah}

Rumusan masalah dari penelitian ini adalah:

1. Bagaimana pengaruh analisis fundamental terhadap harga saham perusahaan sektor pertanian yang sahamnya tercatat dalam BEI pada periode 2005-2011?

2. Bagaimana pengaruh analisis teknikal terhadap harga saham perusahaan sektor pertanian yang sahamnya tercatat dalam BEI periode 2005-2011?

3. Bagaimana pengaruh pengaruh faktor-faktor makroekonomi terhadap harga saham perusahaan sektor pertanian yang sahamnya tercatat dalam BEI periode 2005-2011?

\section{Tujuan Penelitian} berikut:

Adapun tujuan dari penelitian ini adalah sebagai

1. Menganalisis pengaruh analisis fundamental terhadap harga saham perusahaan sektor pertanian yang sahamnya tercatat dalam BEI pada periode 2005-2011

2. Menganalisis pengaruh analisis teknikal terhadap harga saham perusahaan sektor pertanian pada periode 2005-2011 yang sahamnya tercatat dalam BEI.

3. Menganalisis pengaruh faktor-faktor makro ekonomi terhadap harga saham perusahaan sektor pertanian yang sahamnya tercatat dalam BEI periode 2005-2011?

\section{LANDASAN TEORI DAN HIPOTESIS}

\section{Harga Saham}

Harga suatu saham digunakan investor sebagai acuan dalam melakukan transaksi di pasar saham (Sunardi, 2010). Harga saham merefleksikan seberapa besar kekuatan permintaan dibandingkan kekuatan penawaran terhadap suatu saham. Makin banyak investor yang ingin membeli saham, sementara banyaknya investor yang ingin menjual tetap maka harga saham akan cenderung naik (Endri, 2012). Sebaliknya, makin banyaknya investor yang ingin menjual saham sementara banyaknya investor yang ingin membeli saham cenderung tetap maka harga saham akan cenderung turun

\section{Analisis Fundamental}

Analisis fundamental adalah studi tentang ekonomi, industri, dan kondisi perusahaan untuk mem- 
perhitungkan nilai dari saham perusahaan. Analisis fundamental menitik beratkan pada data-data kunci dalam laporan keuangan perusahaan untuk memperhitungkan apakah harga saham sudah diapresiasikan secara akurat. Analisis fundamental merupakan metode analisis saham dengan menganalisa data-data atau informasi yang berhubungan dengan kinerja perusahaan, umumnya laporan keuangan menjadi sumber utama dalam analisis ini termasuk penggunaan rasio-rasio saham seperti laba per lembar saham atau Earning Per Share (EPS), Price Earning Ratio (PER), dan lain-lain (Fakhruddin \& Hendy, 2008)

Perubahan harga saham setiap waktu tidak dapat diprediksi apabila pelaku investasi, khususnya perusahaan, tidak melakukan suatu analisis. Analisis yang paling sesuai dengan harga saham adalah analisis fundamental, karena dengan analisis fundamental perusahaan, akan memperhitungkan risiko dan harga saham yang terjadi maupun yang sedang terjadi. Analisis fundamental diperlukan untuk memperhitungkan risiko dan keuntungan yang bisa diterima berupa dividen atau capital gain.

\section{Analisis Teknikal}

Analis teknikal berupaya untuk mengidentifikasi pola dan tren harga dalam pasar keuangan serta berupaya untuk mengeksploitasi pola tersebut. Para analis berupaya menemukan prototipe patron seperti misalnya pola pembalikan yang sangat dikenal dengan istilah Inggris head and shoulders (pola berbentuk seperti kepala dan bahu), serta mempelajari pula berbagai pola seperti harga, volume, dan pergerakan rata-rata dari harga.

\section{Suku Bunga Bank Indonesia}

Definisi BI rate menurut Bank Indonesia (2011d) adalah suku bunga instrumen Bank Indonesia yang ditetapkan pada Rapat Dewan Gubernur triwulanan untuk berlaku selama triwulan berjalan, kecuali ditetapkan berbeda oleh Rapat Dewan Gubernur bulanan dalam triwulan yang sama. BI rate digunakan sebagai acuan dalam pelaksanaan operasi pengendalian moneter untuk mengarahkan agar ratarata tertimbang suku bunga SBI satu bulan hasil lelang operasi pasar terbuka berada di sekitar BI rate. Selanjutnya suku bunga SBI dengan tenor satu bulan diharapkan mempengaruhi suku bunga pasar uang antar bank dan suku bunga jangka yang lebih panjang. Perubahan BI rate (SBI tenor satu bulan) ditetapkan secara konsisten dan bertahap dalam kelipatan 25 basis poin (Bank Indonesia, 2011d).

\section{Harga Minyak Dunia}

Harga minyak mentah dunia diukur dari harga spot pasar minyak dunia, pada umumnya yang digunakan menjadi standar adalah West Texas Intermediate (WTI) atau Brent. Minyak mentah yang diperdagangkan di WTI adalah minyak mentah yang berkualitas tinggi. Minyak mentah tersebut berjenis light-weight dan memiliki kadar belerang yang rendah. Minyak jenis ini sangat cocok untuk dijadikan bahan bakar. Hal ini menyebabkan harga minyak ini dijadikan patokan bagi perdagangan minyak di dunia.

Harga minyak mentah di WTI pada umumya lebih tinggi lima sampai enam dolar daripada harga minyak Organization of the Petroleum Exporting Countries (OPEC) dan lebih tinggi satu hingga dua dolar dibanding harga minyak Brent. Harga minyak Brent merupakan campuran dari 15 jenis minyak mentah yang dihasilkan oleh 15 ladang minyak yang berbeda di Laut Utara. Kualitas minyak mentah Brent tidak sebaik minyak mentah WTI, meskipun begitu masih tetap bagus untuk disuling menjadi bahan bakar. Harga minyak mentah Brent menjadi patokan di Eropa dan Afrika. Harga minyak Brent lebih tinggi sekitar empat dolar dari harga minyak OPEC.

\section{Kurs Mata Uang}

Nilai tukar mata uang asing (exchange rate) atau nilai kurs menyatakan hubungan nilai di antara satu kesatuan mata uang asing dan kesatuan mata uang dalam negeri. Kurs adalah rasio antara suatu unit mata uang tertentu dengan sejumlah mata uang lain yang bisa ditukar pada waktu tertentu. Kurs mata uang asing mengalami perubahan nilai yang terus menerus dan relatif tidak stabil. Perubahan nilai ini dapat terjadi karena adanya perubahan permintaan dan penawaran atas suatu nilai mata uang asing pada masing-masing pasar pertukaran valuta dari waktu ke waktu. Perubahan permintaan dan penawaran itu sendiri dipengaruhi oleh adanya kenaikan relatif tingkat bunga baik secara bersama-sama maupun sendiri-sendiri terhadap negara.

\section{Hipotesis Penelitian}

Hipotesis dalam penelitian ini adalah:

$\boldsymbol{H}_{\boldsymbol{0} \boldsymbol{a}}$ : Tidak ada pengaruh yang signifikan antara analisis fundamental (EPS, BVS, PER, ROA, $R O E$, $P B V$, dan $D E R$ ) terhadap harga saham sektor pertanian.

$\boldsymbol{H}_{l a}$ : Ada pengaruh yang signifikan antara analisis fundamental (EPS, BVS, PER, ROA, ROE, PBV, dan $D E R$ ) terhadap harga saham sektor pertanian. 
$\boldsymbol{H}_{\boldsymbol{b b}}$ : Tidak ada pengaruh yang signifikan analsis teknikal (Tren Harga Saham) terhadap harga saham sektor pertanian.

$\boldsymbol{H}_{l b}$ : Ada pengaruh yang signifikan antara analsis teknikal (Tren Harga Saham) terhadap harga saham sektor pertanian.

$\boldsymbol{H}_{\boldsymbol{\theta} \boldsymbol{c}}$ : Tidak ada pengaruh yang signifikan antara faktor makroekonomi (BI rate, harga minyak dunia, dan kurs rupiah) terhadap harga saham sektor pertanian.

$\boldsymbol{H}_{I c}$ : Ada pengaruh yang signifikan antara faktor makroekonomi (BI rate, harga minyak dunia, dan kurs rupiah) terhadap harga saham sektor pertanian.

\section{METODE PENELITIAN}

\section{Desain Penelitian}

Pengambilan dan pengumpulan data yang akan digunakan dalam penelitian ini akan dilakukan di Bursa Efek Indonesia (BEI). Penelitian akan dilakukan dari bulan Februari 2013-April 2013. Dalam rangka pengumpulan data penulis menggunakan metode riset pustaka yaitu metode penelitian yang digunakan untuk mendapatkan informasi yang dibutuhkan dengan cara mempelajari buku-buku atau literatur yang berhubungan dengan permasalahan yang akan dibahas dalam penelitian ini

Penelitian ini menggunakan data sekunder yang diperoleh dari perusahaan sektor pertanian yang sudah go public pada periode 2005-2011. Data sekunder pada penelitian ini berupa data laporan keuangan perusahaan sektor pertanian periode 20052011 yang diperoleh dengan mengunjungi BEI dan mengunduh melalui website www.idx.co.id (Bursa Efek Indonesia, 2011a \& 2011b). Berikut perusahaan sektor pertanian yang sudah go public pada periode 2005-2011.

Tabel 2. Perusahaan yang Go Public dari Sektor Pertanian Periode 2005-2011

\begin{tabular}{ll}
\hline Sektor Usaha & Kode Saham \\
\hline PT Astra Agro Lestari, Tbk & AALI \\
PT PP London Sumatra,Tbk & LSIP \\
PT Bakrie Sumatra Plantation,Tbk & UNSP \\
PT Tunas Muda Lampung & TBLA \\
PT Smart, Tbk & SMAR \\
PT Bumi Teknoultra, Tbk & BTEK \\
PT Cipendawa Tbk & CPDW \\
PT Dharma Samudra Fishing,Tbk & DSFI \\
\hline
\end{tabular}

Sumber: Bursa Efek Indonesia, 2011a
Data sekunder kedua berupa data harga saham closing price setiap triwulan yang didapat dengan mengunduh melalui website www.idx.co.id dan www.duniainvestasi.com. Data sekunder yang terakhir adalah data ekonomi makro yaitu harga minyak dunia yang didapat melalui website www.economa gic.com, kurs rupiah melaui website www.ortax.org dan suku bunga Bank Indonesia melalui website www.bi.go.id.

\section{Metode Pengumpulan Data}

Data sekunder dikumpulkan dari dokumendokumen yang ada dan melalui media online yang mendukung penelitian ini. Dalam rangka pengumpulan data penulis menggunakan metode riset pustaka yaitu metode penelitian yang digunakan untuk mendapatkan informasi yang dibutuhkan dengan cara mempelajari buku-buku atau literatur yang berhubungan dengan permasalahan yang akan dibahas dalam penelitian ini.

\section{Metode Pengolahan Data dan Analisis Data}

Menurut Sugiyono (2008), analisis deskriptif adalah salah satu metode yang dilakukan untuk menganalisa data dengan mengumpulkan data-data yang sesuai dengan sebenarnya, kemudian data-data tersebut disusun, diolah dan dianalisis untuk dapat memberikan gambaran masalah yang ada. Penelitian ini akan menggunakan software Eviews 6 dan Microsoft Excel untuk pengolahan dan analisis data.

Tabel 3. Rumus Rasio Keuangan pada Analisis Fundamental

\begin{tabular}{|c|c|}
\hline Alat Analisis & Rumus \\
\hline Earning Per Share (EPS) & Laba Bersih/Jumlah Saham \\
\hline & Beredar \\
\hline $\begin{array}{l}\text { Price Earning Ratio } \\
(P E R)\end{array}$ & $\begin{array}{l}\text { Harga Pasar saham/Earning } \\
\text { per Share }\end{array}$ \\
\hline $\begin{array}{l}\text { Book Value Pershare } \\
(B V P)\end{array}$ & Total Ekuitas/Jumlah Saham \\
\hline Return on Asset (ROA) & $\begin{array}{l}\text { (Laba Bersih Sebelum Pa- } \\
\text { jak/Total Aset) x 100\% }\end{array}$ \\
\hline Return on Equity (ROE) & $\begin{array}{l}\text { (Laba Bersih Sebelum Pa- } \\
\text { jak/Total Ekuitas) x } 100 \%\end{array}$ \\
\hline $\begin{array}{l}\text { Return on Investment } \\
\text { (ROI) }\end{array}$ & $\begin{array}{l}\text { Laba Usaha Setelah Pa- } \\
\text { jak/Total Aktiva) x 100\% }\end{array}$ \\
\hline Price Book Value (PBV) & $\begin{array}{l}\text { Harga Pasar Saham/Book } \\
\text { Value per Share }\end{array}$ \\
\hline Debt Equity Ratio (DER) & Total Hutang/Total Ekuitas \\
\hline
\end{tabular}

Sumber: Fakhruddin \& Hendy, 2008

Tren merupakan salah satu indikator yang penting dalam melakukan analisis teknikal karena tu- 
juan analisis teknikal adalah untuk mendapatkan indikasi apakah tren harga itu berakhir, berlanjut, dan berbalik arah. Dalam penelitian ini lebih melihat bagaimana pergerakan tren saham sektor pertanian dalam tiga bulan terakhir apakah saham tersebut naik, turun, atau tetap setiap pergerakan akan diberikan nilai sebagai penanda naik turunnya suatu harga saham untuk naik diberi angka 1 , turun diberi angka -1 dan tetap diberi angka 0 .

Dalam penelitian ini akan dilihat indikatorindikator dari faktor-faktor makro ekonomi yang paling berpengaruh terhadap harga saham. Setelah ditinjau penelitian ini memilih faktor BI rate yang dikeluarkan Bank Indonesia, kurs rupiah terhadap dollar dan harga minyak dunia sebagai faktor-faktor makroekonomi yang nantinya akan dilihat pengaruhnya terhadap harga saham. Ada tiga pendekatan yang dilakukan dalam menganalisa model panel data yaitu pendekatan kuadrat terkecil (pooled least square), pendekatan efek tetap (fixed effect), dan pendekatan efek acak (random effect).

Model persamaan yang digunakan dalam persamaan adalah sebagai berikut:

$Y_{i t}=\beta_{0}+\beta_{1} X_{(1) i t}+\beta_{2} X_{(2) i t}+\beta_{3} X_{(3) i t}+\beta_{4} X_{(4) i t}+\beta_{5} X_{(5) i t}+\beta_{6} X_{(6) i t}+$ $\beta_{7} X_{(7) i t}+\beta_{8} X_{(8) i t}+\beta_{9} X_{(9) i t}+\beta_{10} X_{(10) i t}+\beta_{11} X_{(11) i t}+\beta_{12} X_{(11) i t}+\varepsilon_{i t}$

Dengan:

$Y_{i t}=$ Harga Saham Perusahaan Sektor Pertanian; $X_{I}=$ Earning Per Share (EPS); $X_{2}=$ Book Value Pershare $(B V S) ; X_{3}=$ Price Earning Ratio $(P E R) ; X_{4}=$ Return on Asset (ROA); $X_{5}=$ Return on Equity $(R O E) ; X_{6}=$ Price Book Value $(\mathrm{PBV}) ; \mathrm{X}_{7}=$ Debt Equity Ratio $(D E R) ; X_{8}=$ Tren Harga Saham; $X_{9}=\mathrm{BI}$ rate $X_{10}=$ Harga minyak dunia; $X_{11}=$ Kurs rupiah; $X_{12}=$ Variabel dummy; krisis ekonomi saham $i$ triwulan $t$.

Pengujian asumsi klasik yang digunakan yaitu uji normalitas, multikolinearitas, heteroskedastisitas, dan autokorelasi.

\section{HASIL PENELITIAN DAN PEMBAHASAN}

\section{Uji Chow}

Data yang digunakan dalam penelitian ini merupakan data yang stasioner dan menyebar normal. Data merupakan data unbalance karena ada beberapa data perusahaan yang tidak tersedia di sumber data.

Tabel 4. Hasil Uji Chow

\begin{tabular}{llll}
\hline Effects Test & Statistic & d.f. & Prob. \\
\hline Cross-section F & 3,639425 & $(7,195)$ & 0,0010 \\
\hline
\end{tabular}

Nilai $p(0,0010)<$ alpha $5 \%$ maka tolak $\mathrm{H}_{0}$. artinya model yang terbaik adalah Least Squares Dummy Variable (LSDV)/Fixed Effect (FEM). Ber- dasarkan Tabel 4 yang menyajikan hasil perhitungan uji chow maka $H_{0}$ ditolak dan $H_{l}$ diterima, yaitu dalam penelitian ini pendekatan Fixed Effect (FEM) lebih baik daripada pendekatan model dengan PLS. FEM merupakan pendekatan yang memasukkan variabel boneka untuk menghindari kolinearitas sempurna antar variabel sedangkan PLS adalah restricted model. Model ini menerapkan intercept yang sama untuk seluruh individu. Namun adanya variabel dummy ini dapat mengurangi banyaknya derajat bebas yang dapat mempengaruhi koefisien dari parameter yang diestimasi.

\section{Analisis Model Regresi Panel}

Berdasarkan hasil uji chow yang memilih model LSDV/FEM sebagai model terbaik berikut hasil dari model $L S D V / F E M$.

Hasil analisis regresi di atas menunjukkan bahwa faktor Book Value per share (BVS), Price Book Value (PBV), Debt Equity Ratio (DER), tren harga saham, BI rate, harga minyak dunia, dan kurs rupiah secara bersama-sama memberikan pengaruh terhadap harga saham sektor pertanian sementara faktor Earning Per Share (EPS), Price Earning Rasio (PER), Return on Asset (ROA) dan Return on Equity (ROE) tidak memberikan pengaruh terhadap harga saham sektor pertanian. Harga saham dilihat dari harga penutupan setiap triwulan dalam model disimbolkan dengan variabel $Y$. Banyaknya cross section (i) adalah delapan perusahaan dan data time series adalah tujuh tahun.

$$
\begin{aligned}
Y_{i l}= & 7.08-5,95 \text { EPS }_{i t}+0,0001 \text { BVS }_{(i t)}-1,13 \text { PER }_{i t}+ \\
& 4,87 \text { ROA }_{i t}+0,0002 \text { ROE }_{i t}+0,12 P B V_{(I T)}-0,03 \\
& \text { DER }_{(i t)}+0,06 \text { Trend Saham }_{(i t)}-0,03 \text { Bi Rate }_{(i t)} \\
& +0,002 \text { Minyak Dunia }_{(i t)}-9,33 \text { Kurs Rupiah }_{(i t)} \\
& +\epsilon_{i t}
\end{aligned}
$$

Nilai $R^{2}$ menunjukkan bahwa variabel $X$ mampu menjelaskan pengaruhnya terhadap $Y$ sebesar $99,30 \%$ sedang sisanya $0,70 \%$ dijelaskan oleh faktor lain selain $X$ (dan tidak dimasukan ke dalam persamaan di atas). Variabel Book Value Per share (BVS), Price Book Value (PBV), Debt Equity Ratio (DER), tren harga saham, BI rate, harga minyak dunia, dan kurs rupiah berpengaruh signifikan pada level $1 \%$.

\section{Analisis Pengujian Asumsi Klasik Model Regresi Panel}

\section{Uji Normalitas}

Uji normalitas dalam penelitian ini bertujuan untuk mengetahui apakah data yang diteliti dalam penelitian ini berdistribusi normal atau tidak. Model regresi yang baik adalah model yang memiliki data yang terdistribusi secara normal. 
Tabel 5. Hasil Model Regresi Panel

\begin{tabular}{|c|c|c|c|c|}
\hline Variable & Coefficient & Std. Error & $t$-Statistic & Prob. \\
\hline$E P S$ & $-5,95 \mathrm{E}-05$ & $8,73 \mathrm{E}-05$ & $-0,681620$ & 0,4963 \\
\hline$B V S$ & 0,000108 & $5,40 \mathrm{E}-05$ & 1,993453 & 0,0476 \\
\hline PER & $-1,13 \mathrm{E}-05$ & $6,47 \mathrm{E}-05$ & $-0,175169$ & 0,8611 \\
\hline$R O A$ & 4,87E-05 & 0,002374 & 0,020493 & 0,9837 \\
\hline$R O E$ & 0,000207 & 0,000275 & 0,752493 & 0,4527 \\
\hline$P B V$ & 0,123196 & 0,012539 & 9,825345 & 0,0000 \\
\hline DER & $-0,035320$ & 0,005583 & $-6,326120$ & 0,0000 \\
\hline Tren Saham & 0,060809 & 0,010975 & 5,540498 & 0,0000 \\
\hline BI Rate & $-0,032928$ & 0,014596 & $-2,255907$ & 0,0252 \\
\hline Harga Minyak Dunia & 0,002517 & 0,000935 & 2,691821 & 0,0077 \\
\hline Kurs Rupiah & $-9,33 \mathrm{E}-05$ & $2,79 \mathrm{E}-05$ & $-3,342227$ & 0,0010 \\
\hline$D U M M Y$ & 0,008996 & 0,050261 & 0,178977 & 0,8581 \\
\hline C & 7,089851 & 0,351316 & 20,18081 & 0,0000 \\
\hline$A R(1)$ & 0,851054 & 0,035524 & 23,95730 & 0,0000 \\
\hline \multicolumn{5}{|c|}{ Effects Specification } \\
\hline \multicolumn{5}{|c|}{ Weighted Statistics } \\
\hline$R$-squared & \multicolumn{3}{|c|}{ 0,993090Mean dependent var } & 6,998834 \\
\hline Adjusted R-squared & \multicolumn{3}{|c|}{ 0,992381 S.D. dependent var } & 3,161006 \\
\hline S.E. of regression & \multicolumn{3}{|c|}{ 0,196116Sum squared resid } & 7,499979 \\
\hline$F$-statistic & \multicolumn{3}{|c|}{1401,284 Durbin-Watson stat } & 1,532875 \\
\hline $\operatorname{Prob}(F$-statistic $)$ & \multicolumn{3}{|c|}{0,000000} & \\
\hline \multicolumn{5}{|c|}{ Unweighted Statistics } \\
\hline$R$-squared & \multicolumn{3}{|c|}{ 0,988302 Mean dependent var } & 6,457659 \\
\hline Sum squared resid & \multirow{2}{*}{\multicolumn{3}{|c|}{$\begin{array}{r}\text { 7,937883 Durbin-Watson stat } \\
0,85\end{array}$}} & 1,422675 \\
\hline Inverted AR Roots & & & & \\
\hline
\end{tabular}

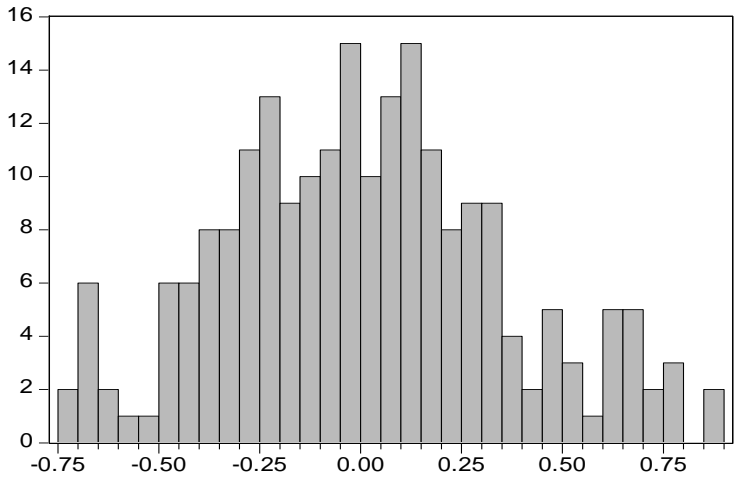

\begin{tabular}{|lc|}
\hline \multicolumn{2}{|l|}{ Series: Standardized Residuals } \\
Sample 2005Q2 2011Q4 \\
Observations 216 \\
Mean & 0.010522 \\
Median & -0.003544 \\
Maximum & 0.878018 \\
Minimum & -0.725051 \\
Std. Dev. & 0.348333 \\
Skewness & 0.209488 \\
Kurtosis & 2.719769 \\
& \\
Jarque-Bera & 2.286636 \\
Probability & 0.318760 \\
\hline
\end{tabular}

\section{Gambar 1. Uji Normalitas Data}

Dapat disimpulkan bahwa Nilai $p(0,318760)>$ alpha 5\% maka terima $H_{0}$ artinya residual menyebar normal. Semua data yang tersedia dalam penelitian ini terdistribusi secara normal.

\section{Uji Multikolinearitas}

Multikolinearitas adalah kondisi adanya hubungan linier antar variabel independen yang ditandai $R^{2}$ yang tinggi tetapi banyak variabel independen yang tidak signifikan. Nilai Adjusted $R^{2}$ yang cukup tinggi disertai dengan banyaknya variabel yang signifikan menunjukkan tidak terdapat multikolinearitas dalam model.
Penelitian ini menunjukkan bahwa antar variabel tidak memiliki koefisien yang cukup besar. Uji multikolinieritas untuk data panel dihitung berdasarkan matrik data rata-rata setiap panel (perusahaan) pada deret waktu 2005-2011. Dapat disimpulkan menurut uji Klein, jika nilai $R^{2}>$ dari nilai korelasi antar peubah independen dalam hal ini 99,30\% > 80,2\% maka dapat dikatakan tidak terdapat multikolinieritas.

\section{Uji Heteroskedastisitas}

Uji Heteroskedastisitas bertujuan untuk menguji apakah dalam sebuah model regresi terjadi ketidak- 
samaan varians dari residual suatu pengamatan ke pengamatan lain. Jika varians dari residual suatu pengamatan ke pengamatan yang lain tetap maka disebut homokedastisitas jika varians berbeda disebut heteroskesdastisitas. Model regresi yang baik adalah tidak terjadi heterokedastisitas atau disebut Nilai sum square resid weighted $(7,499979)<$ sum square resid unweighted $(7,937883)$ tidak ada heteroskedastisitas artinya model regresi ini homoskedastisitas.

\section{Uji Autokorelasi}

Autokorelasi adalah hubungan antara residual satu observasi dengan residual observasi lainnya. Autokorelasi menunjukkan adanya korelasi antara variabel itu sendiri pada pengamatan yang berbeda waktu atau individu. Salah satu langkah yang dapat dilakukan untuk mendeteksi autokorelasi adalah dengan menggunakan uji Durbin-Watson. Uji DurbinWatson pada model logaritma menunjukkan nilai $D W$ $=1,532875$ yang berarti tidak ada autokorelasi dengan demikian dapat disimpulkan bahwa model regresi penelitian ini tidak terjadi autokorelasi.

\section{Analisis Fundamental Kinerja Perusahaan Sektor Pertanian}

Secara garis besar faktor fundamental perusahaan sektor pertanian di dominasi oleh PT Astra Agro Lestari, Tbk. (AALI) diikuti dengan PT London Sumatera, Tbk., dan PT Sinar Mas Agro, Tbk. Ketiga perusahaan tersebut memiliki kinerja yang positif dapat dilihat dari nilai EPS dari ketiga perusahaan tersebut memberikan nilai yang tinggi artinya perusahaan dapat memberikan keuntungan yang besar terhadap investor berupa deviden maupun gain. Hal tersebut dapat terjadi mengingat komoditi ekspor utama dari ketiga perusahaan tersebut adalah $\mathrm{CPO}$ yang mana terjadi peningkatan ekspor CPO terutama ke negara-negara Eropa maupun Amerika. Selain itu dari faktor-faktor fundamental lainnya seperti book value per share, price earning ratio, return on asset, return on equity, price book value, dan debt equity ratio memiliki nilai yang positif yang menunjukan kinerja fundamental yang kuat pada ketiga perusahaan tersebut.

\section{Analisis Teknikal Terhadap Harga Saham Sektor Pertanian}

Dapat dilihat dari tren harga saham PT Astra Agro Lestari, Tbk., PT London Sumatera, Tbk., PT Sinar Mas Agro, Tbk., dan kelima perusahaan lainnya memperlihatkan kondisi yang fluktuatif. Pada tahun
2007 rata-rata perusahaan sektor pertanian mengalami lonjakan kenaikan pada harga saham namun kenaikan tersebut tidak dapat bertahan pada tahun 2008. Krisis global menyebabkan volume perdagangan pada perusahaan sektor pertanian.

\section{Pergerakan Harga Saham Sektor} Pertanian 2005 - 2011

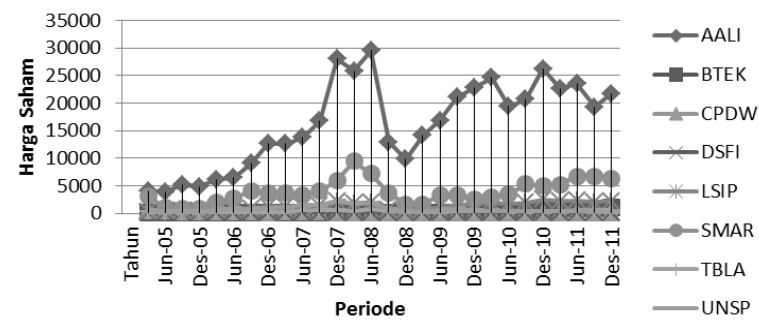

Gambar 2. Pergerakan Harga Saham Sektor Pertanian 2005-2011

Perlambatan pertumbuhan ekspor disebabkan oleh menurunnya permintaan dunia yang disebabkan oleh resesi perkonomian, menyebabkan perlambatan laju ekspor pertanian, menurunya harga komoditas dunia dan meningkatnya tingkat pengangguran global yang akan mempengaruhi jumlah produksi komoditi ekspor terutama crude palm oil (CPO) yang menjadi sumber utama ekspor perusahaan sektor pertanian.

\section{Analisis Faktor Makroekonomi yang Mempenga- ruhi Harga Saham Sektor Pertanian}

Posisi tertinggi BI rate pada bulan Desember 2005 yaitu pada posisi $12,75 \%$ dan terjadi penurunan yang sangat singnifikan pada akhir tahun 2011. Hal ini disebabkan Bank Indonesia mewaspadai tingginya risiko dan ketidakpastian di pasar keuangan global serta kecenderungan menurunnya kinerja perekonomian global akibat permasalahan utang dan fiskal di Eropa dan AS. Level tertinggi tingkat suku bunga Bank Indonesia yaitu di level $12,75 \%$ dan mengalami penurunan pada triwulan pertama tahun 2006. Tingkat suku bunga yang tinggi tersebut bertujuan untuk menekan kenaikan inflasi yang terjadi pada triwulan awal tahun 2006 hingga triwulan kedua tahun 2006 yaitu $17,92 \%$ pada triwulan pertama tahun 2006 dan 15,4\% pada triwulan kedua tahun 2006.

Posisi kurs US dolar terhadap rupiah pada Maret 2009 yang merupakan level tertinggi sepanjang periode penelitian terjadi sebagai respon dari krisis ekonomi global yang terjadi yang turut berimbas pula terhadap perekonomian nasional. Tingkat inflasi yang tinggi sebagai respon awal dari krisis ini yaitu berada di level 11,68\% pada triwulan keempat tahun 2008 
mengakibatkan turunnya nilai mata uang rupiah, sehingga daya tukarnya terhadap mata uang asing seperti mata uang US dolar juga ikut melemah pada level Rp11.575 per US dolar pada Maret 2009.

Posisi harga minyak dunia mencapai nilai tertinggi pada Juni 2008 mencapai $\$ 133.930$ per barel ini merupakan rekor tertinggi sepanjang masa dikarenakan krisis global pada tahun 2008. Meningkatnya konsumsi didasarkan pada rendahnya tingkat suku bunga Bank Sentral Amerika Serikat yang mengakibatkan tersedianya sumber pendanaan dengan biaya yang murah sehingga mendorong perusahaan untuk melakukan ekspansi bisnisnya, sebab kenaikan harga minyak didasarkan pada meningkatnya permintaan, bukan berkurangnya penawaran, maka kenaikan harga minyak sendiri baik secara langsung maupun tidak langsung mendorong kenaikan harga saham khusnya sektor pertanian.

\section{Implikasi Manajerial}

Kenaikan tingkat suku bunga BI rate ini akan menurunkan harga saham. Hal ini menandakan bahwa tingkat kepekaan dari variabel perubahan harga saham sektor pertanian dalam merespon perubahan tingkat suku bunga BI lebih besar. Apabila dikaitkan dengan kondisi fundamental keuangan saham sektor pertanian, pengaruh yang ditunjukkan dari perubahan harga saham AALI, BTEK, CPDW, DSFI, LSIP, SMAR, TBLA dan UNSP yang merespon perubahan tingkat suku bunga BI rate paling besar kedua dan signifikan, dapat dijelaskan melalui rata-rata capital gain triwulan dari keseluruhan saham sektor pertanian serta rata-rata tingkat pengembalian per bulan dari bulan ke- $t$ terhadap bulan $t-l$ sebagai ukuran daya tarik saham sektor pertanian untuk dapat dipilih oleh investor.

Bagi investor yang melihat kenaikan kurs US dolar yang terjadi akan menilai bahwa terdapat potensi keuntungan yang dapat terealisasi jika investor menjual US dolar yang dimilikinya. Potensi keuntungan tersebut didapatkan dari selisih harga penjualan US dolar dengan harga pembelian US dolar. Hal ini akan mendorong investor untuk menjual US dolar yang dimilikinya untuk dikonversikan ke dalam bentuk rupiah. Dengan dikonversikannya US dolar ke dalam bentuk rupiah maka hal ini akan menambah jumlah rupiah yang dimiliki. Kelebihan jumlah rupiah yang dimiliki tersebut kemudian diinvestasikan kembali ke dalam portofolionya ke dalam bentuk saham, tabungan dan deposito ataupun sektor riil.

Bagaimana dengan kondisi fundamental perusahaan dapat dilihat dari Rasio yang mengukur perbandingan antara jumlah kewajiban dan aktiva va- las US dollar dapat menjelaskan pengaruh yang ditunjukkan oleh perubahan harga saham AALI dalam merespon perubahan kurs US dolar. Nilai rasio kewajiban per aktiva valas US dolar pada saham sektor pertanian ini memiliki kecenderungan rasio paling besar dalam mempengaruhi perubahan harga saham AALI, BTEK, CPDW, DSFI, LSIP, SMAR, TBLA dan UNSP. Nilai rasio kewajiban per aktiva valas US dolar menunjukkan seberapa besar pendanaan berupa valas US dolar dibiayai oleh aktiva valas US dolar.

Dengan meningkatnya nilai kurs US dolar akan menyebabkan jumlah pendanaan dalam bentuk rupiah yang dibutuhkan perusahaan untuk membiayai kewajiban valas US dolar menjadi bertambah. Apabila suatu perusahaan memiliki rasio kewajiban per aktiva valas US dolarnya tinggi maka menunjukkan bahwa peningkatan kewajiban valas US dolar yang terjadi belum diimbangi dengan peningkatan aktiva valas US dolar yang dimiliki. Hal ini menyebabkan perusahaan tersebut membutuhkan tambahan pendanaan dalam bentuk rupiah yang lebih banyak untuk membeli setiap satu US dolar yang dibutuhkan dalam membiayai setiap kewajiban valas US dolar perusahaan.

Investor akan berhati-hati dalam memilih saham yang memiliki nilai rasio kewajiban per aktiva valas US dolar yang besar yang menandakan sangat berisikonya saham tersebut untuk diinvestasikan di tengah naiknya kurs US dolar. Investor akan memilih saham yang memiliki nilai rasio kewajiban per aktiva valas US dolar yang kecil untuk diinvestasikan.

Bagaimana dengan tren saham perusahaan sektor pertanian hampir memiliki kecendrungan yang positif dengan pergerakan harga yang cenderung memiliki tren positif hanya saja dengan adanya krisis pada 2008 menyebabkan beberapa dari perusahaan memiliki ketidakstabilan harga saham yang menurun namun dengan melihat kesimpulan dari tren yang positif wajar apabila harapan harga saham sektor pertanian akan cendrung meningkat pada tahun berikutnya. Dengan melihat kondisi fundamental, faktor-faktor makroekonomi dan teknikal memang sudah sewajarnya investor lebih berhati-hati dalam memilih saham pada sektor pertanian dari kesimpulan yang ada dan melihat segala aspek tersebut dapat disimpulkan bahwa investor layak untuk melakukan pembelian terhadap saham sektor pertanian.

\section{SIMPULAN DAN SARAN}

\section{Simpulan}

1. Faktor fundamental perusahaan sektor pertanian didominasi oleh PT Astra Agro Lestari, Tbk. (AALI). Selain AALI terdapat pula perusahaan 
lainya seperti PT Smart, Tbk. (SMAR) dan PT PP London Sumatra, Tbk. (LSIP). Hal tersebut dapat dilihat dari faktor-faktor fundamental seperti earning per share, book value pershare, price earning ratio, return on asset, return on equity, price book value, dan debt equity ratio yang memberikan pengaruh terhadap harga saham sektor pertanian.

2. Berdasarkan analisis teknikal, pergerakan harga saham pertanian mengalami fluktuasi yang tinggi karena adanya krisis pada tahun 2008 hal ini diperkuat dari hasil penelitian ini bahwa variabel tren harga saham berpengaruh signifikan terhadap harga saham sektor pertanian.

3. Berdasarkan faktor makroekonomi menunjukan pergerakan kurs rupiah, BI rate dan harga minyak dunia memberikan pengaruh terhadap harga saham sektor pertanian

\section{Saran}

Bagi emiten saham AALI, BTEK, CPDW, DSFI, LSIP, SMAR, TBLA dan UNSP diharapkan untuk senantiasa mengelola kondisi keuangannya terutama yang tampak pada rasio keuangan dalam laporan keuangan yang dipublikasikan, karena kecenderungan investor dalam mengambil keputusan berinvestasi pada keempat saham ini diduga lebih melihat kondisi kekuatan dan prospek fundamental keuangan perusahaan dibandingkan dengan perubahan kondisi makro ekonomi yang terjadi. Untuk penelitian selanjutnya, diharapkan dapat memasukkan rasio keuangan perusahaan serta variabel makroekonomi lain seperti neraca pembayaran, ekspor-impor, dan kondisi ekonomi lain ke dalam model guna menduga faktor-faktor yang mempengaruhi harga saham.

\section{DAFTAR REFERENSI}

Badan Pusat Statistik. 2010. Berita Resmi Statistik: Pertumbuhan Ekonomi Indonesia Triwulan I 2011, (http://www.bps.go.id., diakses 10 Maret 2013).

Bank Indonesia. 2011a. Kurs Rupiah Terhadap US Dolar, (http://www.bi.go.id., diakses 10 Maret 2013).

2011b. Laporan Inflasi (Indeks Harga Konsumen): Berdasarkan Perhitungan Inflasi Tahunan, (http://www.bi.go.id., diakses 10 Maret 2013).

2011c. Perkembangan Besaran Moneter Dalam Milyar Rupiah Periode Desember 2006Mei 2011, (http://www.bi.go.id., diakses 10 Maret 2013).

2011d. Tingkat Suku Bunga BI Rate, (http://www.bi.go.id., diakses 12 Pebruari 2013).

Bursa Efek Indonesia. 2011a. Laporan Keuangan Perusahaan Terdaftar di Bursa Efek Indonesia Maret 2007-Maret 2011, (http://www.idx.go.id., diakses 5 Maret 2013).

2011b. Ringkasan Kinerja Saham. (http:// www.idx.co.id., diakses 10 Maret 2013).

Endri, E. 2012. Analisis Teknikal dan Fundamental Saham: Aplikasi Model Data Panel. Jurnal Akuntabilitas, 8(1): 90-96.

Fakhruddin \& Hendy, M. 2008. Teori Portofolio dan Analisis Investasi. Yogyakarta: BPFE.

Sugiyono. 2008. Metode Penelitian Kunatitatif, Киаlitatif, dan $R \& D$. Bandung: Alfabeta.

Sunardi, H. 2010. Pengaruh Penilaian Kinerja dengan ROA dan EVA Terhadap Return Saham pada Perusahaan yang tergabung Dalam Indeks LQ 45 Di Bursa Efek Indonesia. Jurnal Akuntansi, 2(1): 70-92. 